\title{
Governing the Arctic Ocean
}

\author{
Oran R. Young \\ Bren School of Environmental Science and Management \\ University of California (Santa Barbara) \\ Santa Barbara, CA 93106, USA \\ oran.young@gmail.com
}

\begin{abstract}
$\underline{\text { Abstract }}$
The biophysical state change currently underway in the Arctic Ocean is opening up the region to new and intensified human activities. While the pace of development is not as rapid as many expected a few years ago, increased human activities are generating new needs for governance pertaining to the Arctic Ocean. The critical shortcomings of the existing arrangements applicable to this area arise from jurisdictional and sectoral fragmentation. A more effective governance system for the entire Arctic Ocean must rest on the constitutive foundation provided by the UN Convention on the Law of the Sea. The toolkit provided by the law of the sea includes at least four distinct though not mutually exclusive approaches: (i) the application of specific provisions of UNCLOS (e.g. Arts. 122 and 123) to address emerging needs for governance in the Arctic Ocean, (ii) the development of UNCLOS implementing agreements that are applicable to the Arctic Ocean, (iii) the use of measures adopted by UN specialized agencies (e.g. IMO, FAO), and (iv) the creation of subsidiary bodies, such as regional fisheries management organizations or regional seas arrangements, tailored to the circumstances of the Arctic Ocean. A critical review of these approaches reveals their strengths and weaknesses as mechanisms for meeting emerging needs for governance in the Arctic Ocean. The way forward is likely to feature the development of a multi-functional arrangement that applies to human activities in the entire Arctic Ocean and that allows for distinct categories of members possessing different rights and responsibilities.
\end{abstract}

\section{$\underline{\text { Key words }}$}

Governance, institutional fragmentation, constitutive arrangements, operational regimes, UN Convention on the Law of the Sea 


\section{$\underline{\text { Abstract }}$}

\section{Governing the Arctic Ocean}

The biophysical state change currently underway in the Arctic Ocean is opening up the region to new and intensified human activities. While the pace of development is not as rapid as many expected a few years ago, increased human activities are generating new needs for governance pertaining to the Arctic Ocean. The critical shortcomings of the existing arrangements applicable to this area arise from jurisdictional and sectoral fragmentation. A more effective governance system for the entire Arctic Ocean must rest on the constitutive foundation provided by the UN Convention on the Law of the Sea. The toolkit provided by the law of the sea includes at least four distinct though not mutually exclusive approaches: (i) the application of specific provisions of UNCLOS (e.g. Arts. 122 and 123) to address emerging needs for governance in the Arctic Ocean, (ii) the development of UNCLOS implementing agreements that are applicable to the Arctic Ocean, (iii) the use of measures adopted by UN specialized agencies (e.g. IMO, FAO), and (iv) the creation of subsidiary bodies, such as regional fisheries management organizations or regional seas arrangements, tailored to the circumstances of the Arctic Ocean. A critical review of these approaches reveals their strengths and weaknesses as mechanisms for meeting emerging needs for governance in the Arctic Ocean. The way forward is likely to feature the development of a multi-functional arrangement that applies to human activities in the entire Arctic Ocean and that allows for distinct categories of members possessing different rights and responsibilities.

\section{$\underline{\text { Key words }}$}

Governance, constitutive arrangements, institutional fragmentation, operational regimes, UN Convention on the Law of the Sea

\section{Introduction}

The biophysical state change currently underway in the Arctic Ocean is opening up this once remote and forbidding marine region to a variety of new or intensified human activities (National Research Council 2015). Prominent among these are commercial shipping, offshore energy development, the harvesting of fish and marine mammals, shipbased adventure tourism, scientific research, and initiatives aimed at the protection of ecologically and socially sensitive areas. Less likely but certainly not out of the question are activities involving bioprospecting, drug trafficking, and piracy. 
The onrush of these human activities seems substantially less precipitous today than it did just a few years ago in the immediate aftermath of the collapse of sea ice in the Arctic Basin starting in 2007. We no longer hear breathless assertions about the "scramble for the Arctic," the "Arctic gold rush," or the prospect of "armed clashes" in the Arctic (Sale and Potapov 2010; Howard 2009; Borgerson 2008). Nevertheless, continued growth in the scope and intensity of human activities in the waters of the Arctic Ocean over the course of the near future seems inevitable. A reasonable conclusion is that we should treat the slowing of the pace of development in the Arctic as an opportunity to think carefully about emerging issues of governance and about the design of institutional arrangements tailored to address specific needs for governance pertaining to the Arctic Ocean rather than as an excuse to put off to some later time a systematic effort to address this subject.

This article addresses this topic in several steps. It begins with an exercise in institutional diagnostics, seeking to identify the most prominent characteristics of the emerging needs for governance relating to the Arctic Ocean and to anticipate how these needs are likely to evolve during the foreseeable future. In the process, it seeks to make clear why existing governance systems applicable to the region are not adequate to meet emerging needs for governance arising in this marine region. It then identifies and explores various ways to address these emerging needs. It focuses on the toolkit of available institutional options and analyzes the extent to which various tools, individually or in combination, are likely to prove both effective in terms of problem solving and realistic in terms of political feasibility in the context of the conditions prevailing in the Arctic today. A brief concluding section offers some initial thoughts about next steps that 
should appeal to those responsible for addressing the challenge of governing the Arctic Ocean going forward.

\section{The challenge of Arctic Ocean governance}

The Arctic Ocean today is hardly the "wild west" (Corell 2008). There is no shortage of governance arrangements applicable to human activities in this marine region (Young 2012). Some of these arrangements are broad multilateral environmental agreements applicable to the Arctic as well as to other regions of the world. Perhaps the most important of these is the 1982 UN Convention on the Law of the Sea, widely regarded as a constitutive arrangement providing general ground rules covering the full range of human activities in marine areas and serving as a solid foundation on which to build operational regimes dealing with specific concerns. Other prominent examples are the 1946 International Convention for the Regulation of Whaling, the 1973/1978 International Convention for the Prevention of Pollution from Ships, the 1992 UN Framework Convention on Climate Change, and the 2001 Stockholm Convention on Persistent Organic Pollutants. Other existing arrangements reflect explicit efforts to downscale broader international governance systems to address specific conditions arising in the Arctic. The 2011 Agreement on Cooperation on Aeronautical and Maritime Search and Rescue in the Arctic, for instance, is a regional application of more general provisions set forth in the 1979 International Convention on Search and Rescue; the 2013 Agreement on Cooperation on Marine Oil Pollution, Preparedness, and Response in the Arctic is a regional application of the broader provisions of the 1990 International Convention on Oil Spill Preparedness, Response, and Cooperation. Still other arrangements applicable to the Arctic are products of initiatives on the part of specialized 
agencies in the UN System. The International Maritime Organization's (IMO) International Code for Ships Operating in Polar Waters (the Polar Code) adopted in 2015 and applicable to commercial vessels operating in Arctic waters is a prominent example.

Nor does this exhaust the reservoir of existing governance systems pertinent to the Arctic Ocean. The spatial coverage of OSPAR, a regional seas arrangement whose primary concern is marine pollution in Europe, extends to the North Pole in the European Arctic. The five coastal states (the A5) have a history of taking steps to address specific needs for governance in the Arctic within the framework provided by the overarching law of the sea. ${ }^{1}$ During the cold war, for example, these states reached agreement on the terms of the 1973 Agreement on the Conservation of Polar Bears. In the intervening years, the coastal states have taken additional steps to address threats to polar bears in specific areas. Recently, the A5 have extended this practice to fisheries, issuing a Declaration Concerning the Prevention of Unregulated High Seas Fishing in the Central Arctic Ocean in 2015. Strictly speaking, the provisions of this declaration apply only to nationals of the coastal states. But these states have announced their intention to consult with others in an effort to extend the applicability of this regulatory initiative. They have already taken steps to make good on this intention. The A5 have repeatedly voiced their support as well for procedures established under the terms of UNCLOS as the proper means for addressing issues relating to extended jurisdiction over the seabed in the Arctic Ocean. Canada, Denmark/Greenland, Norway, and Russia have all made submissions (or partial submissions) regarding the delimitation of their seabed jurisdiction in the Arctic to the Commission on the Limits of the Continental Shelf (CLCS), a body established under

\footnotetext{
${ }^{1}$ Prior to the signing of UNCLOS 1982, the four 1958 Geneva Conventions on the Law of the Sea set forth existing law dealing with maritime issues.
} 
Art. 76 of UNCLOS and provided with a mandate to evaluate the credibility of the scientific evidence supporting such submissions.

Beyond this, each of the coastal states has adopted regulatory arrangements dealing with human activities taking place within its own Exclusive Economic Zone in the Arctic Ocean, as coastal states are authorized to do under the overarching provisions of UNCLOS. Each of these states has established regimes dealing with oil and gas development and with fishing occurring within its EEZ. Canada and Russia have developed more or less elaborate regulatory systems applicable to shipping in the Northwest Passage and the Northern Sea Route, respectively. There are disagreements pertaining to some of these arrangements (Byers 2013). The United States and a number of other states, for example, contest Canada's claim that the Northwest Passage is included within the internal waters of Canada, raising questions regarding the applicability of the provisions of UNCLOS Art. 38 regarding transit passage to these waters. But even in these cases, the relevant states have generally found pragmatic ways to deal with the issues on a day-to-day basis, without prejudicing their legal positions (Kirkey 1994-1995).

Given this rather dense network of governance arrangements applicable to the Arctic Ocean, what reason is there to be concerned at this juncture about the challenge of governing the Arctic Ocean? Is this ocean not in comparatively good shape when it comes to the existence of governance systems covering a broad range of human activities? Are there significant differences between the Arctic Ocean and other oceans regarding needs for governance? Similar queries are pertinent to thinking about the governance of marine systems in any regional setting. In the case of the Arctic Ocean, the 
principal concern centers on the consequences of jurisdictional and sectoral fragmentation with regard to the governance of human activities taking place today in the Arctic Ocean and, perhaps more important, likely to become more prominent during the foreseeable future.

Jurisdictional fragmentation is a matter of the division of a region into a number of segments that are distinct with regard to their jurisdictional status. Sectoral fragmentation, on the other hand, arises from the existence of distinct regimes dealing with specific activities, such as shipping, oil and gas development, fishing, and so forth. Fragmentation need not pose a serious challenge when human activities occur at a low level and do not interact with one another to any significant degree. But fragmentation gives rise to mounting needs for governance as human activities become more intense and wide-ranging (Crowder et al. 2006). Consider the implications of these general observations with regard to ongoing developments pertaining to the Arctic Ocean.

The Arctic Ocean (and its marginal seas including Hudson Bay) is the smallest and shallowest of the planet's oceans, covering an area of some 14 million square kilometers. But it is jurisdictionally complex. The immediate and highly complex coastal zones of the Arctic Ocean are included within the internal waters or territorial seas of the five Arctic coastal states (Pharand 1988). The whole of the Bering Strait, for example, lies within the territorial seas of the Russian Federation and the United States (Berkman, Vylegzhanin, and Young 2016). Taken together, the territorial waters and EEZs of the coastal states encompass well over half of the Arctic Ocean. This leaves an area of $\sim 2.8$ million square kilometers in the middle of the ocean as high seas as defined under the terms of UNCLOS and fully subject to the provisions dealing with high seas set forth in 
Part VII of the convention. This area is open to a range of activities on the part of signatories to UNCLOS or states like the US that have not ratified UNCLOS but treat the provisions of Part VII as having the status of customary international law.

Jurisdiction over the seabed beyond the limits of the EEZs, however, is another story. Coastal states are allowed to extend their jurisdiction over the seabed beyond the limits of the EEZ under somewhat complicated conditions set forth in UNCLOS Art. 76. ${ }^{2}$ Norway's position regarding its seabed jurisdiction in the Arctic is comparatively straightforward. The CLCS took a generally positive view of Norway's 2006 submission, and there are no active disputes regarding the limits of Norway's seabed jurisdiction in the Arctic (CLCS 2009). But Canada, Denmark/Greenland, and Russia assert jurisdiction over extensive and partially overlapping segments of the seabed in the Arctic (Byers 2013). All three have made submissions (or partial submissions) to the CLCS. But the opinions of the CLCS are likely to be some time in coming and are not legally binding in any case. Some sort of negotiated settlement will almost certainly be required to resolve this problem. In the end, it is likely that most of the seabed of the Arctic Ocean will come under the jurisdiction of one or another of the coastal states.

Several other provisions of UNCLOS also are applicable to the Arctic Ocean. These include the general provisions covering innocent passage and transit passage as well as the Arctic-specific provisions of Art. 234 dealing with ice-covered areas and granting coastal states authority to adopt non-discriminatory measures to deal with problems of marine pollution attributable to the presence of extensive sea ice. Whether

\footnotetext{
${ }^{2}$ Because of its failure to ratify UNCLOS, the US is unable to take advantage of this provision.
} 
the recession of sea ice in the Arctic Basin will affect the applicability of Art. 234 is an open question.

What problems are likely to arise as a consequence of this complex pattern of jurisdictional arrangements as human activities in the Arctic increase in scope and intensity? Some human activities cut across jurisdictional boundaries; ships operating in the Arctic often pass through waters subject to the regulations of different states and may well traverse portions of the high seas as well. A commercial vessel that sails between Rotterdam and Shanghai using the Northern Sea Route, for example, will pass through several jurisdictional zones. In such cases, the critical issue centers on the harmonization of regulatory arrangements to avoid complications arising from the need to satisfy distinct and in some cases poorly coordinated or even conflicting requirements applying to different zones. In other cases, the problem arises from the fact that the resources of interest are mobile and likely to move in and out of distinct jurisdictional zones. The most striking cases involve fish and marine mammals, including whales and polar bears. Bilateral arrangements are sufficient to address this concern in some cases; the bilateral arrangement between Norway and Russia creating the means to manage the fish stocks of the Barents Sea in a cooperative manner is a good example (Stokke 2012). In the event that commercially significant stocks of fish begin to show up in the central Arctic Ocean, however, multilateral arrangements would become important. Because a sizable fraction of this area is high seas, such arrangements would need to include interested non-Arctic states to be effective. A different situation arises with regard to offshore oil and gas development. During the foreseeable future, any such development is almost certain to occur in areas subject to the jurisdiction of one or another of the coastal states (Gautier et 
al. 2009). The regulatory arrangements of the relevant states would apply to such activities. But pollution arising from accidents involving exploration and production facilities or transportation systems might well be another story. Pollution originating at a specific site could easily cross jurisdictional boundaries affecting the coastal zones or EEZs of adjacent states or areas of the high seas. Overall, jurisdictional complexity can impede efforts to manage human activities effectively, efficiently, and equitably and to cope with side effects that are not confined to areas under the jurisdiction of a single state.

Sectoral fragmentation, by contrast, arises from the existence of distinct regimes dealing with a variety of human activities. The issue here centers on what those concerned with governance have come to regard as the problem of institutional interplay (Oberthür and Stokke 2011). So long as human activities are few and far between, sectoral fragmentation is not likely to pose a problem. Those interested in an area like the Arctic Ocean can pursue their interests with little or no impact on each other. But this is apt to change as human activities intensify (McLeod and Leslie 2009). Increasing ship traffic can harm marine mammals (due to ship strikes, the discharge of wastes, noise pollution, and so forth), introduce invasive species, and generate pollution (e.g. black carbon) that accelerates the melting of sea ice. Offshore oil and gas development and especially marine pollution arising as a result of such development can prove harmful to fish, marine mammals, and sea birds. The creation of marine protected areas can restrict the activities of fishers and limit the use of sensitive areas as sea lanes at least on a seasonal basis. In all these cases, the problem arises from the fact that human activities 
impinging on one another are subject to distinct governance systems that (often) do not include procedures for sorting out the resultant tensions or conflicts.

The problem of institutional interplay is familiar at the national level where responsibility for managing distinct human activities is distributed across a variety of public agencies. In the US, for example, the National Oceanic and Atmospheric Administration handles fisheries management, while the Bureau of Ocean Energy Management handles issues relating to offshore oil and gas development. There is no straightforward procedure for coordinating the actions of the two agencies. If anything, these divisions are sharper at the international level. In the case of the Arctic Ocean, for example, the IMO is the lead agency regarding commercial shipping; each of the coastal states handles offshore energy development within its own EEZ, and efforts are currently underway to put in place some sort of issue-specific international regime capable of dealing with the possible development of commercial fishing. In many cases, the resultant interactions are dealt with on an ad hoc basis with the outcomes arising in specific cases determined as much by bureaucratic politics and the distribution of bargaining power among the key players as by principles of rational management or stewardship (Chapin, Kofinas, and Folke 2009). This approach leaves much to be desired, especially as the continuing growth of human activities intensifies these problems of institutional interplay. Under the circumstances, those concerned with marine policy at both the national level and the international level have begun to search for procedures, such as marine spatial planning, to be used in sorting out these issues in the interests of minimizing conflicts arising from these interactions and enhancing the public interest (Young et al. 2007; Ehler 2014). This is not an easy task under the best of circumstances; 
success is commonly elusive. Nevertheless, it may be feasible to make progress in a case like the Arctic Ocean where the relevant human activities remain at relatively early stages in their development.

\section{Potential solutions}

Is there a need to take immediate action to address the challenge of institutional fragmentation with regard to the Arctic Ocean? One response to this question is to argue that for now at least we should adopt a watching brief, tracking developments in this realm closely and evaluating the options while putting off actions designed to create new governance arrangements until we have a clearer sense of what is needed. In fact, the Arctic boom seems much less dramatic today than it did even a few years ago. Commercial shipping in the Arctic is not likely to increase rapidly and dramatically; there is little reason to expect sizable numbers of container ships to ply Arctic waters anytime soon (Brigham 2013; Gunnarsson 2013). Sharp reductions in world market prices for oil and gas are causing a marked decline in the pace of offshore energy development in the Arctic; Shell's recent retreat from its exploratory work in the Chukchi Sea signals a dramatic shift in this regard (Pumphrey 2015). In any case, offshore activities involving energy development will take place within the EEZs of individual coastal states during the foreseeable future and be subject to the governance systems of these states covering offshore energy development. Most marine biologists are skeptical about the emergence of commercially significant fish stocks in the Arctic any time soon, except in areas like the Barents Sea where coastal state regulations are in force and bilateral arrangements between Norway and Russia have been in place for some time (Hollowed, Planque, and Loeng 2013). The most acute environmental problems in the region (e.g. the recession 
and thinning of sea ice, ocean acidification) are products of global forces; they cannot be addressed through the development of Arctic regimes.

This reality check is not a reason to ignore or to put off indefinitely the development of a more integrated governance system for the Arctic Ocean. Nevertheless, changing circumstances are providing us with some breathing room in this realm. We can afford to think carefully about a range of options before jumping to facile conclusions and embracing the first attractive idea that comes along. Adopting this perspective, this section canvasses the options; it is not intended to produce specific recommendations regarding the best way to respond to the emerging challenge of governing the Arctic Ocean.

The point of departure for this assessment is the proposition that any successful response to the challenge of governing the Arctic Ocean must rest on the foundation provided by UNCLOS. All the interested states - both Arctic and non-Arctic - have stated clearly and repeatedly that they are committed to dealing with issues of Arctic Ocean governance within this framework. Meeting in Ilulissat, Greenland in the spring of 2008, for example, representatives of the A5 stated explicitly that "[t]his framework provides a solid foundation for responsible management by the five coastal states and other users of this Ocean ... We see no need to develop a new comprehensive international legal regime to govern the Arctic Ocean" (Ilulissat Declaration 2008). For the most part, the A5 have acted in a manner consistent with this declaration in the course of the intervening years. Notably, they have adhered to the procedures established under UNCLOS even as they seek to delimit their jurisdiction over segments of the seabed in the Arctic Ocean. The Arctic Council, whose membership includes Finland, Iceland, and 
Sweden as well as the A5, has joined this consensus among the Arctic states regarding the applicability of UNCLOS.

For their part, leading non-Arctic states also have asserted repeatedly that UNCLOS provides the proper legal foundation for addressing matters of governance relating to the Arctic Ocean (Lunde, Yang, and Stensdal 2016). Spokesmen for China, Japan, and Korea as well as France, Germany, the UK, and the European Union have affirmed their views in this regard in a variety of fora. In the process, of course, they have observed that all signatories to UNCLOS have rights to engage in a variety of activities in the high seas portion of the Arctic Ocean, that rights to transit passage and innocent passage apply in the Arctic, and that certain applications of the idea of the common heritage of humankind are relevant to the Arctic Ocean. They do not regard these rights as subject in any way to the actions of the A5 or the Arctic Council.

In some respects, the consensus regarding the applicability of UNCLOS to the Arctic Ocean seems promising with regard to prospects for developing cooperative governance systems to deal with issues arising in conjunction with increases in human activities in this region. Lest we succumb to an excess of optimism, however, consider the following features of this situation. In the Ilulissat Declaration, the A5 also announced that "[b]y virtue of their sovereignty, sovereign rights, and jurisdiction in large areas of the Arctic Ocean the five coastal states are in a unique position to address the possibilities and challenges" arising from rising human activities in this area (Ilulissat Declaration 2008). They drew from this the inference that "... the five coastal states have a stewardship role in protecting" the Arctic Ocean (Ilulissat Declaration 2008). This may sound promising. But no knowledgeable observer could avoid the inference that the A5 
were claiming a paramount role vis-à-vis other states with regard to matters of Arctic Ocean governance. For its part, the Arctic Council has adopted similar language in spelling out the rules of procedure regarding the participation of non-Arctic state observers (Arctic Council 2013).

Conversely, the leading non-Arctic states have made it clear that they do not see meetings of the A5, from which they are excluded, or the Arctic Council, in which they are relegated to the role of observers and asked to the acknowledge the special role of the Arctic states in addressing matters of Arctic governance, as appropriate forums for dealing with important issues of Arctic Ocean governance. As rightsholders under the provisions of UNCLOS, they see no reason to defer to the A5 or to the council in considering suitable ways to come to terms with the emerging challenges of Arctic Ocean governance. The parliament of the European Union, for example, has called for the creation of a marine sanctuary around the North Pole, without turning to the Arctic Council as the proper venue for discussing this proposal (World Maritime News 2014).

One inference to be drawn from this discussion is that the Arctic Council does not provide the most promising forum for addressing the big picture of Arctic Ocean governance. While the council has established a Task Force on Arctic Marine Cooperation (Task Force on Arctic Marine Cooperation 2015), the A5 have acted repeatedly to address issues of Arctic Ocean governance outside the forum provided by the Arctic Council. The most recent case is the issuance of the 2015 declaration on fishing in the central Arctic Ocean by the A5 without consulting the remaining members of the council (Finland, Iceland, and Sweden) or providing an opportunity for full participation on the part of indigenous peoples' organizations. Nor are the non-Arctic 
states, frustrated by the limits placed on the participation of observers in the activities of the council, likely to respond positively to initiatives in this realm on the part of the council. It is possible that the council may take the initiative in devising arrangements (e.g. the proposed Arctic Ocean Coordinating Agreement) dealing solely with marine areas under the jurisdiction of council members (Baker and Yaeger 2015). But such initiatives would do little to meet the challenge of fragmentation described in the previous section. They might well fall victim to disagreements between the A5 and the remaining members of the Arctic Council in any case. In the case of the 2015 declaration on fishing in the central Arctic Ocean, for example, Iceland lodged vigorous protests regarding its exclusion from the initiative. Although the US has identified Arctic Ocean safety, security, and stewardship as a major theme of its council chairmanship (20152017), therefore, it is hard to imagine significant achievements in this realm beyond measures to operationalize agreements (e.g. the search and rescue agreement) that are already in place. ${ }^{3}$

Where does this leave us regarding efforts to address the challenge of fragmentation in Arctic Ocean governance arising from the growth of human activities in this region? A reasonable conclusion is that we need to take UNCLOS as our point of departure and consider the toolkit of measures available to those seeking to construct operational arrangements on this constitutive foundation. This toolkit includes at least four distinct approaches to addressing needs for governance in the Arctic Ocean. One approach is to apply specific provisions of UNCLOS (e.g. Arts. 76, 122, 123, 234) to respond to emerging needs for governance in the Arctic Ocean. A second approach is to

\footnotetext{
${ }^{3}$ For example, the establishment in October 2015 of the Arctic Coast Guard Forum among the eight member states of the Arctic Council may help to increase capacity to deal with maritime emergencies in the Arctic (Coast Guard Compass 2015).
} 
focus on the development of implementing agreements (e.g. the 1995 straddling stocks agreement) and on their application to the specific issues arising in the Arctic Ocean. A third approach is to rely on the initiatives of UN specialized agencies (e.g. IMO, FAO) dealing with specific issues within the overarching framework provided by UNCLOS. Yet a fourth approach is to create subsidiary bodies, such as regional fisheries management organizations (RFMOs) or regional seas agreements (RSAs), to address Arctic Ocean issues located within the overarching ambit of UNCLOS and authorized under the provisions of Art. 197 dealing with "cooperation on a global or regional basis." These approaches are not altogether mutually exclusive; it may make sense to apply elements of two or more of them at the same time. For example, UNCLOS implementing agreements may work together with initiatives on the part of UN specialized agencies. In such cases, however, it is essential to be alert to complications arising from the occurrence of institutional interplay.

Consider the relevance of each of these mechanisms as they might apply to meeting emerging needs for governance in the Arctic Ocean. Some of the specific provisions of UNCLOS are already in play with regard to issues of Arctic Ocean governance. As noted in the previous section, for instance, the Arctic coastal states are adhering faithfully to the provisions of Art. 76 in submitting evidence pertaining to their jurisdiction over the seabed beyond the limits of their EEZs. Perhaps the most intriguing prospect regarding specific provisions of UNCLOS, however, centers on the idea of applying the provisions of Part IX dealing with enclosed or semi-enclosed seas to the Arctic Ocean (United Nations 2013: Ch. 17). Is it plausible to treat the Arctic Ocean as an enclosed or semi-enclosed sea, defined in UNCLOS Art. 122 as “... a gulf, basin or sea 
surrounded by two or more States and connected to another sea or the ocean by a narrow outlet or consisting entirely or primarily of the territorial seas and exclusive economic zones of two or more coastal States" (United Nations 1983)?

There is no simple answer to this question. Whereas most would agree on characterizing the Black Sea and the Mediterranean Sea as enclosed or semi-enclosed seas, many would question the applicability of this status to an entire ocean, even one as small as the Arctic Ocean. Nevertheless, this approach has several attractive features as a way forward in addressing the challenge of governing the Arctic Ocean. For one thing, Art. 123 envisions an integrated approach to management covering multiple sectoral activities and applying to the relevant area as a whole. In addition, it calls for an approach in which the coastal states take the lead either "... directly or through an appropriate regional organization," with the proviso that they are to invite "other interested States or international organizations" to cooperate with them in developing and implementing appropriate management practices (United Nations 1983). Such an arrangement might make sense not only because it encourages the development of an integrated governance system but also because it would reflect the actual balance of power between the coastal states and various non-Arctic states asserting an interest in Arctic Ocean governance. Despite the hesitations regarding the applicability of the provisions of Part IX to the case of the Arctic Ocean, therefore, it would be a mistake to rule out the possibility of dealing with the emerging challenge of Arctic Ocean governance through the approach envisioned in Art. 123.

Existing UNCLOS Implementing Agreements (IAs), such as the 1995 fish-stocks agreement, already apply to the Arctic Ocean (UNGA 1995). The most interesting new 
development regarding IAs centers on the push to adopt such an agreement dealing with biodiversity beyond national jurisdiction (UNGA 2015; ENB 2015). What is envisioned in this connection is the development of a legally-binding arrangement covering a range of topics including prospecting for marine genetic resources, benefit sharing, the creation of marine protected areas, the introduction of requirements regarding environmental impact assessments, and procedures for technology sharing. An IA along these lines would apply to the high seas area of the Arctic Ocean as well as similar areas in other parts of the world (Rayfuse 2008). This is clearly an important initiative. From the perspective of meeting the challenge of Arctic Ocean governance, however, it has several drawbacks. One drawback has to do with coverage. The area beyond national jurisdiction in the Arctic Ocean encompasses only $20 \%$ of this marine region; in the absence of integration with governance systems applicable to areas within national jurisdiction the effectiveness of a BBNJ IA in the Arctic would be limited. Another drawback is more political in nature. Negotiations aimed at developing this IA are not expected to get underway before late 2017; it is by no means clear if and when they may produce agreement on the text of the proposed IA. In any case, it seems doubtful at this stage whether all the Arctic coastal states would accept the terms of such an agreement. It is difficult to imagine at this juncture circumstances under which the US would ratify a legally binding agreement of this sort.

Actions on the part of UN Specialized agencies, on the other hand, are a different matter. As noted already, the IMO has taken action to put in place a Polar Code covering commercial shipping in the Arctic; it is expected to enter into force at the beginning of 2017. Should commercial fishing become an option in the Arctic Ocean, the 1995 FAO 
Code of Conduct for Responsible Fisheries would apply to such activities (FAO 1995). It is possible to imagine the development of additional measures (e.g. procedures for identifying those engaging in illegal, unreported and unregulated fishing) under the auspices of the FAO applicable to fishing in the Arctic Ocean. The International Civil Aviation Organization's (ICAO) measures dealing with matters of governance relating to the operations of civil aircraft apply to the airspace above the Arctic Ocean. These are clearly significant measures regarding Arctic Ocean governance. But their capacity to contribute to meeting the challenge of Arctic Ocean governance described in the preceding section is limited. They are sectoral measures that do not address the need for integrated governance. In addition, they are typically limited by the concerns of the key industries involved. The Polar Code, for example, does not include a ban on the burning of heavy fuel oils by ships operating in the Arctic; it has no provisions dealing with the danger of invasive species attached to hulls or cargoes of ships operating in Arctic waters. ${ }^{4}$ This is not to say that those concerned with Arctic Ocean governance should belittle or reject initiatives like the Polar Code. Nevertheless, it does not seem likely that actions on the part of UN specialized agencies can be expected to provide the key to meeting the emerging challenge of Arctic Ocean governance.

This brings us to the idea that subsidiary bodies of the sort that have flourished in other marine areas might prove useful in meeting the challenge of governing the Arctic Ocean. Several existing RFMOs (e.g. the Northeast Atlantic Fisheries Commission, the Northwest Atlantic Fisheries Organization, the North Atlantic Salmon Conservation Organization, the organizational arrangements established under the Central Bering Sea

\footnotetext{
4 To be clear, the Polar Code does recommend that ships operating in Arctic waters should avoid carrying HFOs; global measures, such as the 2001 International Convention on the Control of Harmful Anti-fouling Systems on Ships, apply to Arctic waters as well as other marine systems.
} 
Convention) cover areas close to the Arctic and, in some cases, extending into the Arctic Ocean. It is possible that the idea of creating an Arctic Ocean fisheries organization may come into focus, though no one has advanced a specific proposal along these lines so far. Nevertheless, any such arrangement would be sectoral in nature. While it might address the problem of jurisdictional fragmentation with regard to fisheries, it would do nothing to come to terms with the problem of sectoral fragmentation with regard to Arctic Ocean governance.

Some sort of regional seas agreement might seem more appropriate in this context. Yet it is important to be clear regarding exactly what such an arrangement would entail (Duyck 2014). Many (though not all) of the existing regional seas arrangements operate under the auspices of the UN Environment Programme, an option that would almost certainly be unappealing to the Arctic coastal states which have shown little enthusiasm for UN engagement in matters of Arctic governance. Most regional seas arrangements deal primarily with problems of marine pollution (including pollution from land-based sources), though it is worth noting that there is no formal barrier to including other issues in such arrangements. For example, OSPAR, which many regard as the most successful of the regional seas arrangements, started out life as a means of addressing ship-based and land-based marine pollution but has evolved into a regime that covers a substantially broader range of concerns. ${ }^{5}$ Without doubt, pollution is a matter of growing concern with regard to the governance of the Arctic Ocean. But it is important to bear in mind that the need for sectoral integration makes it important to think in terms of arrangements that are able to encompass a broad range of specific concerns. In addition,

\footnotetext{
5 Formally, OSPAR's coverage extends into the northeastern Atlantic sector of the Arctic. Though it is fair to say that the organization has not devoted much attention to addressing Arctic issues, there has been some talk within this venue about establishing Arctic marine protected areas.
} 
existing RSAs do not provide for different categories of membership to recognize differences in the nature and extent of the rights and interests of the participating states. While it is possible that an Arctic RSA could adopt a different formula with regard to membership, this could easily turn out to be a sticking point for the Arctic coastal states which are not likely to accept any arrangement in which non-Arctic states have a voice that is equal or nearly equal to that of the Arctic coastal states when it comes to making substantive decisions about matters of Arctic Ocean governance.

\section{The way forward}

What conclusions does this analysis suggest regarding next steps in dealing with the challenge of governing the Arctic Ocean? There is merit in some of the issue-specific initiatives currently underway. The adoption of the Polar Code is a significant achievement, though the critics who maintain that it does not go far enough regarding environmental protection have strong arguments on their side. It undoubtedly makes sense to generalize the moratorium on fishing in the central Arctic Ocean adopted by the A5, though the current procedure of proceeding through the inclusion of five additional actors (China, Japan, Korea, Iceland, and the European Union) seems difficult to justify either in terms of the constitutive provisions of UNCLOS or in terms of the idea that the Arctic Council is the preeminent forum for the consideration of Arctic issues.

Yet these initiatives are not likely to be of much help in overcoming the jurisdictional and sectoral fragmentation that lies at the heart of the challenge of Arctic Ocean governance. One initiative that seems, at least superficially, more promising is the establishment of the Task Force on Arctic Marine Cooperation, launched under the auspices of the Arctic Council as part of the US chairmanship program for 2015-2017 
(Iqaluit Declaration 2015). To its credit, the Task Force intends to consider issues arising from sectoral fragmentation. Significantly, it has indicated an interest in the application of the concept of ecosystem-based management to the Arctic Ocean. Concrete proposals like the idea of creating an Arctic Ocean Coordinating Agreement fit within this framework. On further reflection, however, the Task Force is likely to face severe limitations as a means of addressing the challenge of Arctic Ocean governance. It has no authority to build explicit bridges between sectoral initiatives dealing with shipping, fishing, marine protected areas, and so forth. And non-Arctic states are not likely to defer to the Arctic Council when it comes to the development of governance arrangements applicable to areas outside the jurisdiction of the Arctic states themselves. Even the US has chosen to bypass the council when it comes to dealing with issues like potential fishing activities in the central Arctic Ocean. Under the circumstances, the Task Force may be able to do good work in framing issues and exploring options pertaining to Arctic Ocean governance. But it would be unrealistic to expect this body to become a significant source of progressive development in addressing the basic challenge of Arctic Ocean governance.

What is needed is a multifunctional arrangement applicable to the Arctic Ocean as a whole. Drawing on the UNCLOS toolkit, the most relevant options appear to be an arrangement based on the provisions of UNCLOS Art. 123 or some sort of regional seas agreement authorized under the provisions of Art. 197. The Art. 123 option may appeal to the A5 because it envisions arrangements under which the coastal states play the leading roles. But others may well object that it is unacceptable to treat the Arctic Ocean as a semi-enclosed sea as defined in Art. 122. Non-Arctic states, by contrast, may prefer 
the option of a regional seas agreement because such an arrangement is likely to call for equality among all member states with regard to its decisionmaking procedures. For the same reason, the A5 are not likely to agree to an ordinary regional seas agreement for the Arctic Ocean. Bearing in mind the political realities of the Arctic as well as the emerging needs for Arctic Ocean governance, the way forward may be to devise an innovative hybrid arrangement under which there are two categories of members possessing different rights and responsibilities. There are precedents for arrangements of this sort. Perhaps the most relevant case in point is the Antarctic Treaty that establishes two classes of members: Consultative Parties that have the right to vote on matters arising during Antarctic Treaty Consultative Meetings and non-Consultative Parties that have the right to participate in consultative meetings but not to cast a vote (Antarctic Treaty 1959; Triggs 2011). The point is not to propose the adoption of the same formula in the context of a multi-functional arrangement dealing with the challenge of governing the Arctic Ocean. Rather, the purpose of this example is to demonstrate that it is possible to create arrangements featuring more than one class of members. Focusing on the identification and analysis of innovative approaches to membership in an Arctic Ocean governance system may turn out to be a particularly rewarding endeavor for those interested in promoting progress in this realm during the coming years. 
Acknowledgement: The Arctic Options project, funded by the US National Science Foundation under Award No. 1263819, provided support for the preparation of this article.

\section{References}

Antarctic Treaty 1959. Text available at: www.ats.aq/e/ats.htm.

Arctic Council 2013. Observer Manual for Subsidiary Bodies. Text available at: www.arctic-council.org.

Baker, Betsy and Brooks Yaeger 2015. "Coordinated Ocean Stewardship in the Arctic: Needs, Challenges and Possible Models for an Arctic Ocean Coordinating Agreement," Transnational Environmental Law, DOI:10.1017/S2047102515000151.

Berkman, Paul, Alexander Vylegzhanin, and Oran R. Young, 2016. "Governing the Bering Strait Region: Current Status, Emerging Issues, Future Options," Ocean Development and International Law, 47: 186-217.

Borgerson, Scott 2008, "Arctic Meltdown: The Economic and Security Implications of Climate Change," Foreign Affairs, 87: 63-77.

Brigham, Lawson 2013. "International Cooperation in Arctic Marine Transportation," 115-136 in O.R. Young, J.D. Kim, and YH Kim eds., The Arctic in World Affairs: A North Pacific Dialogue on the Future of the Arctic. Seoul and Honolulu: KMI and EWC.

Byers, Michael 2013. International Law and the Arctic. Cambridge: Cambridge University Press.

Chapin, F. Stuart III, Gary P. Kofinas, and Carl Folke eds. 2009. Principles of Ecosystem Stewardship: Resilience-Based Natural Resource Management in a Changing World. New York: Springer.

CLCS 2009. "Summary of the recommendations of the Commission on the Limits of the Continental Shelf in regard to the submission made by Norway in respect to areas in the Arctic Ocean, the Barents Sea, and the Norwegian Sea on 27 November 2006," Text at: www.un.org/depts/los/clcs_new/submissions_files/nov06/nor_rec_snmm.pdf.

Coast Guard Compass 2015. "Establishment of the Arctic Coast Guard Compass," Available at: coastguard.dodlive.mil/2015/10/estabishment-of-the-arctic-coast-gurardforum/.

Corell, Hans 2008. "The North is not the Wild West," Globe and Mail, 28 April.

Duyck, Sebastien, 2014. "Legal Issues Related to Options for a Regional Sea-Type Agreement for the Arctic Ocean," http://dx.doi.org/10.2139. 
Earth Negotiations Bulletin 2015. "BBNJ Working Group Concludes Mandate, Agrees on Nature of Future Instrument," IISD Reporting Services, 23 January.

Ehler, Charles N. 2014. "Pan-Arctic Marine Spatial Planning: An Idea Whose Time Has Come," 199-213 in E. Tedsen, S. Cavalieri, and R.A. Kraemer eds., Arctic Marine Governance: Opportunities for Transatlantic Cooperation. Springer: Heidelberg.

FAO 1995. Code of Conduct for Responsible Fisheries. Text available at: www.fao.org/docrep/005/v9878e/v9878e00.htm.

Gautier, David L., Kenneth J. Bird, Ronald R. Charpentier, Arthur Grantz, David W. Houseknecht, Timothy R. Klett, Thomas E. Moore, Janet K. Pitman, Christopher J. Schenk, John H. Schuenemeyer, Kai Sørensen, Marrilyn E. Tennyson, Zenon C. Valin, and Criag J. Wandrey 2009. "Assessment of Undiscovered Oil and Gas in the Arctic," Science, 324(29 Ma7): 1175-1179.

Gunnarsson, Bjørn 2013. "The Future of Arctic Marine Operations and Shipping Logistics," 37-61 in O.R. Young, J.D. Kim, and Y.H. Kim eds., The Arctic in World Affairs: A North Pacific Dialogue on the Future of the Arctic. Seoul and Honolulu: Korea Maritime Institute and East-West Center.

Hollowed, Anne, Benjamin Planque, and Harald Loeng 2013. "Potential Movement of Commercial Fish and Shellfish Stocks from the Sub-Arctic to the Arctic Ocean," Fisheries Oceanography, 22: 355-370.

Howard, Roger 2009. The Arctic Gold Rush: The New Race for Tomorrow's Natural Resources. London: Contiuum.

Ilulissat Declaration 2008. Declaration from the Arctic Ocean Conference, Iuluissat, Greenland, 27-29 May. Text available at: www.arcticgovernance.org.

Iqaluit Declaration 2015. Declaration of the Ninth Ministerial Meeting of the Arctic Council (24 April). Text available at: www.arctic-council.org.

Kirkey, Christopher 1994-1995. "Smoothing Troubled Waters: The 1988 Canada-United States Arctic Co-operation Agreement," International Journal, 50: 401-426.

Lunde, Leiv, Jian Yang, and Iselin Stensdal eds. 2016. Asian Countries and the Arctic Future. Singapore: World Scientific.

McLeod, Karen and Heather Leslie eds. 2009. Ecosystem-Based Management for the Oceans. Washington, DC: Island Press.

National Research Council 2015. "Arctic Matters: The Global Connection to Changes in the Arctic," http://nas-sites.org/arctic/ 
Oberthür, Sebastian and Olav Schram Stooke eds. 2011. Managing Institutional Complexity: Regime Interplay and Global Environmental Change. Cambridge: MIT Press.

Pharand, Donat 1988. Canada's Arctic Waters and International Law. Cambridge: Cambridge University Press.

Pumphrey, David 2015. "The Impact of Shifting World Energy Markets on Arctic Resource Development," paper presented at the North Pacific Arctic Conference, Honolulu, 5-7 August 2015.

Rayfuse, Rosemary (2008). "Protecting Marine Biodiversity in Polar Areas Beyond National Jurisdiction," RECEIL - Review of European, Comparative, and International Environmental Law, 17: 3-13.

Sale, Richard and Eugene Potapov 2010. The Scramble for the Arctic: Ownership, Exploitation and Conflict in the Far North. London: Frances Lincoln.

Stokke, Olav Schram 2012. Disaggregating International Regimes: A New Approach to Evaluation and Comparison. Cambridge: MIT Press.

Task Force on Arctic Marine Cooperation 2015. A task force of the Arctic Council established in 2015. Terms of reference available at: www.arctic-council.org.

Triggs, Gillian 2011. "The Antarctic Treaty System: A Model of Legal Creativity and Cooperation," 39-50 in P.A. Berkman, M.A. Lang, D.W.H. Walton, and O.R. Young eds., Science Diplomacy: Antarctica, Science, and the Governance of International Spaces. Washington, DC: Smithsonian Institution Scholarly Press.

UNGA 2015. Resolution on Development of an internationally legally-binding instrument under the UN Convention on the Law of the Sea on the conservation and sustainable use of marine biological diversity of areas beyond national jurisdiction. A/RES/69/292 - 19 June.

United Nations 1983. The Law of the Sea. New York: United Nations.

United Nations 1995. Agreement relating to the Conservation and Management of Straddling Fish Stocks and Highly Migratory Fish Stocks. UNGA A/CONF.164/37.

United Nations 2013. Agenda 21: Earth Summit: The United Nations Programme of Action from Rio. New York: CrabCube, Inc.

World Maritime News, "EU Parliament Passes 'the North Pole' Resolution," 14 March 2014. 
Young, Oran R. 2012. "Building an international regime complex for the Arctic: current status and next steps," The Polar Journal, 2: 391-407.

Young, Oran R., Gail Osherenko, Julia Ekstrom, Larry B. Crowder, John Ogden, James A. Wilson, Jon C. Day, Fanny Douvere, Charles N. Ehler, Karen L. McLeod, Benjamin S. Halpern, and Robin Peach 2007. "Solving the Crisis in Ocean Governance: PlaceBased Management of Marine Systems," Environment, 47: 20-32. 


\section{Acronyms/Glossary}

A5 Five Arctic Coastal States

BBNJ Biodiversity Beyond National Jurisdiction

CLCS Commission on the Limits of the Continental Shelf

EEZ Exclusive Economic Zone

FAO Food and Agriculture Organization of the United Nations

HFOs Heavy Fuel Oils

IA UNCLOS Implementing Agreement

ICAO International Civil Aviation Organization

IMO International Maritime Organization

OSPAR Convention for the Protection of the Marine Environment of the NorthEast Atlantic

Polar Code International Code for Ships Operating in Polar Waters

RFMO Regional Fisheries Management Organization

RSA Regional Seas Agreement

UNCLOS United Nations Convention on the Law of the Sea

UNGA United Nations General Assembly 